Latan, H., Jabbour, C. J. C., Sousa Jabbour, A. B. L., de Camargo Fiorini, P., \& Foropon, C. (2019). Innovative efforts of ISO 9001certified manufacturing firms: Evidence of links between determinants of innovation, continuous innovation and firm performance. International Journal of Production Economics, 107526. https://doi.org/10.1016/i.ijpe.2019.107526 


\title{
Innovative efforts of ISO 9001-certified manufacturing firms: evidence of links between determinants of innovation, continuous innovation and firm performance
}

\author{
Hengky Latan \\ Department of Accounting, STIE Bank BPD Jateng, Jl. Soekarno Hatta No 88 Semarang \\ 50196, Indonesia \\ Phone/Fax: +62 243553892 \\ E-mail: latanhengky@gmail.com \\ Charbel Jose Chiappetta Jabbour
}

Montpellier Business School, 2300, avenue des Moulins, 34185 Montpellier, Cédex4, France.

Phone/Fax: +33467102500

E-mail: c.chiappetta-jabbour@montpellier-bs.com

Ana Beatriz Lopes de Sousa Jabbour

Montpellier Business School, 2300, avenue des Moulins, 34185 Montpellier, Cédex4, France.

Phone/Fax: +33 467102500

E-mail: a.sousa-jabbour@montpellier-bs.com

\section{Paula de Camargo Fiorini (CORRESPONDING AUTHOR)}

UFSCar - Federal University of Sao Carlos, Brazil

Address: Rodovia João Leme dos Santos, SP-264, Km 110 - Itinga, Sorocaba - SP, 18052 -

$$
\text { 780, Brazil }
$$

Phone/Fax: 551532296144

Email: paula.fiorini@ufscar.br

\section{Cyril Foropon}

Montpellier Business School, 2300, avenue des Moulins, 34185 Montpellier, Cédex4, France.

Phone/Fax: +33 467102500

E-mail: c.foropon@montpellier-bs.com 


\section{Research highlights}

- This research focuses on continuous innovation and firm performance

- We explore the innovation efforts of ISO 9001-certified firms in an emerging economy

- Determinants of level of innovation are also considered

- The research results point out a number of expected and unexpected research findings 


\title{
Innovative efforts of ISO 9001-certified manufacturing firms: evidence of links between determinants of innovation, continuous innovation and firm performance
}

\begin{abstract}
The innovation efforts of manufacturing firms have recently come to top the agendas of both businesses and industrial policy makers. One persistent research gap in this field relates totesting the relationship between continuous innovation (CI) and firm performance, while taking into account the role of three determinants of firms' level of innovation as core driversin manufacturing firms working under ISO 9001 certification. Anchored in the resource-based view theory $(\mathrm{RBV})$, we shed light on these relationships using an original sample of manufacturing companies listed on the Indonesian Stock Exchange. Our research results provide several implications for ISO 9001-certified manufacturers: (i) evidence of a positive relationship between innovation policy (IP) and CI, whereby IP fosters CI; (ii) evidence of the important role of innovation strategies (INS) in relation to CI; (iii) evidence of a positive relationship between CI and firm performance, whereby CI improves both innovation and financial performance. The implications of our findings for both theory and end-users are presented, with a particular focus on emerging economies, such as Indonesia, a country which has been under-studied in the state-of-the-art literature on operations management.
\end{abstract}

Keywords: Manufacturing; ISO 9001; Innovation; Operations Strategy; Firm performance. 


\section{Introduction}

In the face of rapid changes in all aspects of business, firms need to continuously renew and develop their activities and offerings in order to survive and succeed. For example, renewal of policies, strategies and information systems promises to provide advantages in achieving a competitive edge (Chou et al. 2014; Klingenberg et al. 2013; Xin et al. 2010). Nowadays, to succeed against their competitors, most firms have devoted significant attention to taking steps to improve innovation and its attributes. Innovation is one possible area through which firms can increase growth in sales, market share and profits, and ultimately impact their overall performance (Ferro de Guimarães et al. 2016; Gunday et al. 2011; Shashi et al. 2019). While a plethora of emerging research in the field of operations management highlights the pivotal role that innovation plays in enhancing firm performance (Azadegan and Dooley 2010; Jackson et al. 2016; Jayaram et al. 2014; Lee et al. 2019; Lichtenthaler 2016; Prajogo 2016; Ortiz-Villajos and Sotoca 2018; Wadho and Chaudhry 2018), there have been few empirical studies that address the effect of continuous innovation on firm performance.

Continuous innovation (CI) can be defined as a sustainable effort in building firms' ability to innovate continuously in terms of products, processes, services and so on, either improving existing offerings or developing new ones (Boer et al. 2001; Steiber and Alänge 2013; Terziovski and Sohal 2000). Therefore, CI enables firms to achieve competitive advantage over their competitors and, in turn, has an impact on firm performance as a whole (Hart and Dowell 2011; Porter and Linde 1995).

However, as indicated by scholars in the innovation field (Gunday et al. 2011; Lee et al. 2019), there are cautionary factors for firms that rely solely on erratic plans for innovation. For example, in terms of product innovation, there is a possibility of market failure for new products developed without the application of an innovation strategy for marketing (Gupta et al. 2016; Varis and Littunen 2010), while products may be easily imitated by competitors without the implementation of systematic technological innovation (Hart 1995; Naranjo-Valencia et al. 2011; Simpson et al. 2006). Hence, firms should invest in innovation continuously, to enable them to compete and succeed on a sustainable basis. 
Although previous studies have analyzed various types of innovation including product, process, organizational and marketing innovation - and provided evidence of the relationships between these variables in enhancing firm performance (Camisón and Villar-López 2014; Gunday et al. 2011; Lee et al. 2019), it is necessary to consider the CI perspective, which is a critical organizational capability nowadays due to the volatility of the international market. Innovation in terms of policy (IP), strategy (INS) and technology or information systems (ISI) cannot be ignored in this context and should be taken into account to support CI (Caridi et al. 2012; Jayaram et al. 2014; Liu and Wu 2011; Melville 2010; Oke et al. 2012; Resende et al. 2014; Shi et al. 2018). To date, little has been written about the joint consideration of these three determinants of innovation in terms of strengthening CI to enhance firm performance.

We argue that IP, INS and ISI are at the heart of innovation activities, and are core drivers of firms' innovation (Borrás and Edquist 2013; Oke et al. 2012; Shi et al. 2018). IP relates to the policies applied in firms, including policies to support R\&D and innovation, training and skills, collaboration and networking. Meanwhile, INS is related to firms' strategies for discovering customer needs or incentives for innovation. Finally, ISI relates to the application of new technology or information systems to assist firms' daily operational activities.

Motivated by the aforementioned context, this study aims to test the relationship between CI and firm performance, while taking into account these three determinants of innovation (IP, INS and ISI) as core drivers. We shed light on these relationships using an original sample of manufacturing companies listed on the Indonesian Stock Exchange. We focus specifically on ISO 9001 certified companies, due to the consideration that these firms have adopted a number of relevant quality management principles. As noted by Terziovski and Guerrero (2014), ISO 9001 certification has a positive impact on the process of innovation and firms' ability to innovate. In addition, studies related to innovation and firm performance in developing countries, especially in the Asia-Pacific region, are relatively rare. While there have been widespread studies related to innovation in various regions of the world (Jayaram et al. 2014; Ma et al. 2019; Shao and Lin 2016), most have been conducted in the context of developed countries, and there remains a persistent lack of 
evidence from developing countries, including Indonesia. Based on the Global Innovation Index's (GII) 2018 report, Indonesia ranks 85 ${ }^{\text {th }}$ among 126 countries in terms of innovation, the lowest in this region. In addition, Indonesia's efficiency ratio, which measures the relationship between effort made towards innovation and performance, is also low. Due to the lack of evidence from Indonesia andexisting calls for research into developing countries and innovation (Jugend et al. 2018), research specific to Indonesia in this context has become an urgent demand.

Our study extends the state-of-the-art research in the field of innovation and operations management and provides original evidence in three ways. Primarily, this is the first study to empirically test the relationship between CI and firm performance. While previous studies related to CI and firm performance have been carried out qualitatively (Boer et al. 2001; Steiber and Alänge 2013; Terziovski and Sohal 2000), there is a lack of empirical evidence concerning this relationship. Based on our best knowledge, there have been no previous studies which test the relationship between CI and firm performance empirically, in any context. Hence, our study expands the body of knowledge and adds new empirical evidence concerning both relationshipsto the literature.

Second, our study is the first to consider these three determinants of innovation (i.e. IP, INS and ISI) as driving factors in influencing continuous innovation and, in turn, their impact on firm performance. While a plethora of emerging research studies has dealt with various internal determinants of innovation, including firm size, business strategy, organizational culture, leadership, collaboration within internal functions and organizational structure (e.g. Becheikh et al. 2006; Galende and de la Fuente 2003), there is a lack of empirical evidence addressing the aforementioned determinants of innovation. Moreover, these three determinants are herein jointly analyzed in a single research framework, which is a novelty of this article. Furthermore, the characteristics of these determinants are aligned with the perspective of the Resource Based View (RBV) theory, in which IP, INS and ISI constitute internal factors contributing to CI, and, as suggested by Galende and de la Fuente (2003), CI becomes a source of sustainable competitive advantage. 
Finally, our research contributes fresh evidence in the context of developing countries - in this case, Indonesia. Although a small number of studies related to innovation have been conducted in Brazil, China, India, Pakistan and Rwanda (Aubert 2018; Jajja et al. 2017; Shashi et al. 2019; Wadho and Chaudhry 2018), studies related to innovation in the Indonesian context are relatively rare.

The remainder of this paper is organized as follows. The next section presents the theoretical background and development of hypotheses, followed by the research methodology. Following this, we present our empirical results. Finally, we discuss these results and provide implications that may be useful for both academics and practitioners.

\section{Theoretical background and development of hypotheses}

\subsection{Continuous Innovation}

Innovation is a concept that can be understood as both a process and an outcome to create or apply ideas and solutions and to propose new methods of performing activities, producing products or managing systems, all of which aim for improved performance (Crossan and Apaydin 2010). According to Lianto et al. (2018), CI differs from innovation in that the former is a repeated process of creating or reshaping the capabilities of innovation towards sustainable innovation performance, occurring on a regular basis. This research focuses on CI due to current dynamic changes that are taking place in the market environment, requiring a continuous adjustment of firms' structure and strategy within the market environment. Therefore, CI is an important source of competitive advantage to help firms deal with turbulent market environments.

Lianto et al. (2018) performed a systematic literature review concerning CI, and their main finding was that internal resources are critical success factors for CI. In this sense, the RBV theory is suitable for understanding the determinants of CI, which are internal organizational resources and capabilities that enable firms to innovate (Kostopoulos et al. 2002). There are other organizational theories that also help in studying CI, such as knowledge management and transaction costs (Galende and de la Fuente 2003); however, RBV is focused on organization-level analysis (Crossan and Apaydin 2010). 
RVB theory supports the assumption of a relationship between innovativeness and firm performance (Hart 1995; Hart and Dowell 2011). Innovation, either as a process or an output, can be identified as a firm-specific resource, which is furthermore likely to act as a source of competitiveness (Kamasak 2015). The main principle of the RBV is that the basis of a firm's competitive advantage lies in the application of its uniquecollection of valuable resources and capabilities to innovate (including technology, design, procurement, production, distribution and service). This means that only those firms which can use their resources effectively and have the ability to innovate will gain competitive advantage and, therefore, achieve superior performance. Sustainable competitive advantage is determined by the firm's ability to reconfigure valuable and idiosyncratic resources and to continually foster innovation. Firms' resources can be divided into tangible and intangible assets. Intangible assets include branding, reputation, information knowledge, employee's skills and technological skills. According to the RBV, these resources constitute inimitable, rare and non-tradable unique assets (Barney 1991; Hart 1995; Russo and Fouts 1997).

The innovation process differs among organizations, resulting in varying performance levels. Internal factors can explain such differences in performance (Galende and de la Fuente 2003); therefore, it is important to identify which determinants contribute to organizational innovativeness. In general, factors such as firms' size, business strategy, organizational culture, leadership, collaboration within internal functions and organizational structure (e.g. Becheikh et al. 2006; Galende and de la Fuente 2003) are analyzed as determinants of innovation. The focus of this research is on CI; thus, determinants whose features are likely to renew, adjust and reshape practice and which are related to management systems were selected. The factors mentioned by Becheikh et al. (2006) and Galende and de la Fuente (2003) are less likely to renew practice or be developed easily.

In this paper, we examine the effects of $\mathrm{CI}$ on firm performance, while taking into account the driving factors behind CI. We have divided the driving factors behind CI into three determinants of innovation: innovation policy (IP), innovation strategy (INS) and information systems innovation (ISI). IP is based on total commitment of top management. Top management support, according to Boer and During (2001), enables the provision of 
resources and nurtures the sharing of knowledge and use of a collaborative approach within internal processes. INS should be a continuous process in order to ensure that a firm performs better than its competitors and to maintain such improved performance in the long term (Bates and Flynn 1995). Additionally, ISI assists in enhancing firms' knowledge capabilities on a continuous basis (Joshi et al. 2010).

The following subsections explain the relationship between variables based on our conceptual framework and previous studies, and our hypotheses are thereby derived. First, we hypothesize a direct effect of these types of innovation (IP, INS and ISI) on CI. Second, we hypothesize a relationship between CI and firm performance. Figure 1 presents our conceptual model.

\subsection{Innovation policy and continuous innovation}

Recently, the implementation of innovation policies (IP) has attracted the attention of scholars (Borrás and Edquist 2013; Edler and Fagerberg 2017), and there is growing evidence that IP has a positive influence on firms' actions to innovate (Rogge and Schleich 2018; Costantini et al. 2017; Manjón and Merino 2012). IP can be understood as including all actions taken by firms which influence innovation within their activities. The view that policy may have a role in firms' innovation level has become widespread, and there are indications that IP can trigger firm innovation. Based on the resource-based view of the firm (Hart 1995; Hart and Dowell 2011), we argue that IP promotes the ability of firms to produce CI and that this contributes to competitive advantage, along with firm performance. A previous study conducted by Fabrizio et al. (2017) found a positive and significant relationship between IP and increasing domestic innovation. Another study, by Oke et al. (2012), found a significant positive relationship between human resources policies and firm innovation. We argue that IP provides guidelines for firms to innovate, whereby the innovation activities undertaken depend on this policy in order to improve and speed up CI. Therefore, IP will encourage firms'sustainable innovation activities. Based on the above discussion, we derive our first hypothesis:

H1. Innovation policy has a positive effect on continuous innovation. 


\subsection{Innovation strategy and continuous innovation}

Innovation strategies can be defined as successful implementations of creative ideas within organizations which deliver value to customers (Prajogo 2016). A key motivation for employing an innovation strategy (INS) is to encourage the firm's CI. Firms may attempt to improve CI by adopting appropriate strategies that enable them to keep innovating. For instance, INS should be a continuous process in order to ensure that a firm performs better than its competitors and to maintain such improved performance in the long term (Bates and Flynn 1995).

For example, in facing the challenges of global competition, changes in trends and the needs of customers, managers may implement innovation strategies, and use their resources appropriately to continually innovate (Jayaram et al. 2014; Oke et al. 2012). In other words, the application of innovation strategies represents a response to environmental change by the firm in order to achieve the desired innovation results (Hart and Dowell 2011; Strecker 2009). Through the use of innovation strategies, managers can monitor competitors' innovation activities, further understand the needs of customers, harness the potential of the firm's resources and invest in R\&D. Thus, these practices may have a positive effect on the firm's CI. A firm's ability to perform better than its competitors due to INS is an indicator that such a strategy acts as a unique capability, which aligns INS with RBV theory. Previous research conducted by Oke et al. (2012) has found that innovation strategies have a positive significant effect on the growth of firm revenue. Furthermore, prior studies by Cheng et al. (2010), Jayaram et al. (2014), Prajogo (2016) and Strecker (2009) have found that innovation strategies related to products and processes have a positive significant effect on firm innovation. Another study, by Jajja et al. (2017), found a significant positive relationship between a firm's strategic focus on innovation and supplier innovation focus. Based on the above discussion, we derive our second hypothesis:

H2. Innovation strategy has a positive effect on continuous innovation.

\subsection{Information systems innovation and continuous innovation}

Generally, information systems innovation (ISI) refers to the adoption of new technologies that are integrated into a firm's innovation practices to make changes or 
improvements. Allen (2000) argues that firms' interest in technology-based innovations specifically, information technology (IT) -is related to information systems. Based on the reasoning of RBV, ISI is one source of firms' competitive advantage to achieve the desired innovation and performance (Camisón and Villar-López 2014; Xin et al. 2010; Shao and Lin 2016). For example, investments in and adoption of particular ISI practices, such as IT, can enable CI, either by improving processes or by enabling the firm to offer new products to its customers (Koellinger 2008; Shi et al. 2018). Hence, ISI stimulates changes or significant improvements to existing products and the innovation processes of the firm, and has an impact on increasing productivity and efficiency or on reducing the unit cost of products. Previous studies conducted by Koellinger (2008), Shi et al. (2018) and Xin et al. (2010) have indicated that technological innovation has a positive effect either on product quality or firm innovation. Furthermore, prior studies by Camisón and Villar-López (2014) and Zhang et al. (2018) have found that the use of information systems has a positive effect on product and process innovations. Another study, conducted by Huang and Chen (2010), shows that technological diversity has an influence on firms' innovation performance. Based on the above discussion, we derive our third hypothesis:

H3. Information systems innovation has a positive effect on continuous innovation.

\subsection{Continuous innovation, innovation performance and financial performance}

Scholars have pointed out the important role of innovation in both products and process, in order to reduce operating costs, increase the possibilities of opening new markets and improve the profits of the firm as a whole (García-Zamora et al. 2013; Jajja et al. 2017; Klingenberg et al. 2013; Lee et al. 2019; Lii and Kuo 2016; Prajogo 2016; Shashi et al. 2019; Wadho and Chaudhry 2018). Given that innovation provides added value in terms of productivity and efficiency, this can dramatically improve firm performance. While there are many studies that have demonstrated a positive relationship between innovation and firm performance, few empirical studies also show that innovative firms fail to obtain competitive advantage from their innovation activities (Frank et al. 2016; Koellinger 2008; Kim and Chung 2017). This implies that the innovation carried out by firms should be continuous, and not limited to one particular period or focused on one type 
of innovation alone (Lichtenthaler 2016). Koellinger (2008) argues that investment in unsuccessful innovation is a sunk cost, which will not improve firm performance. According to the natural resource-based view (NRBV), continuous innovation is the key to achieving competitive advantage and improving innovation performance (Hart and Dowell 2011) in turn enhancing firm performance. Most studies related to innovation activities and firm performance show results supporting the perspective of the NRBV. Prior studies conducted by Anandarajan et al. (2007), Bigliardi (2013), Camisón and Villar-López (2014), Černe et al. (2015) and Ferro de Guimarães et al. (2016) have found a significant positive relationship between innovation activity and firm performance. In addition, prior studies conducted by Hult et al. (2004), Klingenberg et al. (2013) and Wadho and Chaudhry (2018) have found that operational innovation and innovation performance have a positive significant influence on financial performance. From such an understanding, our concomitant hypotheses are:

H4a. Continuous innovation has a positive effect on innovation performance.

H4b. Continuous innovation has a positive effect on financial performance.

H5. Innovation performance has a positive effect on financial performance.

Figure 1 illustrates the relationship between continuous innovation and firm performance, including the testing of these types of innovation as driving factors.

$* * * * * * * *$ PLEASE INSERT FIGURE 1 HERE $* * * * * * * *$

\section{Research methodology}

\subsection{Sampling and data collection}

In this study, we test our proposed hypotheses using a sample of chief executive officers (CEOs) of firms selected from a list of ISO 9001-certified companies listed on the Indonesian Stock Exchange (IDX). ISO 9001 is an international certification standard given to companies that have adopted a number of quality management principles, including a focus on customer, innovation and process approaches and continual improvement that aims to improve quality products and processes. 
We chose to study ISO 9001-certified companies because quality and innovation are two complementary business orientations that lead to performance improvement (Manzani et al. 2019). Terziovski and Guerrero (2014) note that ISO 9001 certification has a positive impact on the process of innovation and firms' ability to innovate. In the same vein, Shi et al. (2019) demonstrate that the ISO 9000 quality management system has a positive effect on facilitating the creative process and innovation. Finally, Escrig-Tena et al. (2018) state that hard quality management practices in ISO 9001 certified companies, which include technical and methodological issues, promoting strategic orientation and the use of technologies, lead to process innovation and continuous improvement. Therefore, ISO 9001-certified companies represent an appropriate context to focus on in this study. We began by considering the sampling framework, using data provided by IDX (www.idx.co.id) and the Indonesian Ministry of Industry. Based on these records, there were a total of 1,196 manufacturing companies with ISO 9001 certification operating in Indonesia in 2018. We identified this initial dataset and contacted all ISO 9001-certified manufacturing companies to request participation in our survey, and received approval from 433 companies.

After receiving these companies' agreement to participate in our survey, some initial steps to improve the quality of our survey were taken. We conducted pre-testing to minimize potential bias and ensure precise operationalization of the questionnaire before it was sent to the target respondents (Fowler Jr 2013; Groves et al. 2009). We held discussions with four academic experts and business professionals to assess the content validity of the questionnaire (Rossiter 2011, 2013). These academics were drawn from a pool of reputed senior researchers in the field of innovation and operations management, while the business professionals consulted were either CEOs or consultants. Some improvements were made to the questionnaire in terms of phrasing, clarity, and accuracy of the questions, in order to ensure it was understandable and not vague, ambiguous, or difficult to answer. The final version of this questionnaire was sent to 42 companies for preliminary analysis, and we assessed the validity and reliability of the indicators in the model. The results of our preliminary analysis through principal component analysis (PCA) indicate that the items used are valid and reliable for measuring the variables in our model, 
with loading factors $>0.5$ and Cronbach's alpha $(\alpha)>0.6$, showing the appropriateness of our initial data analysis (see Table 1). According to Hair et al. (2018), these results meet the required standard for preliminary analysis.

We conducted the data collection for this study during December 2018 and January 2019 using online surveys, and made follow-up contact with each respondent via telephone and email. We chose this method because it was considered effective for reaching a broad range of respondents at low cost (Dillman et al. 2014; Groves et al. 2009). In order to increase the response rate, we sent several reminder e-mails and made several phone calls to non-respondents. Within the first two weeks, we contacted all companies by phone to make sure the questionnaire had been received. We then contacted companies again within the following three weeks to encourage respondents to fill out the questionnaire. We also guaranteed the anonymity of responses and non-disclosure of the identity of participating companies. Finally, we provided a two-month cut-off date for completion of this survey, for the purpose of testing non-response bias (Dillman et al. 2014; Fowler Jr 2013). For this reason, we received two waves of responses - those received before and after the specified deadline for conducting this data collection.

We ultimately received 191 returned questionnaires, with 5 being excluded due to incomplete data, giving a response rate of $42.96 \%$. We argue that response rates in this range are considered acceptable in most organizational research studies, including innovation and operations management (Baruch and Holtom 2008; Forza 2002), with a few studies reporting response rates lower than this value. However, to ensure that there were no biases or differences between respondents and non-respondents, we tested non-response bias by comparing those who responded early and those who responded late (Clottey and Grawe 2014; Dalecki et al. 1993). We assumed for these purposes that late respondents are similar to non-respondents, in terms of the time taken to reply. We used a t-test to assess differences in the means of the two sample groups. The desired value to demonstrate that there is no difference between them is $p>0.05$. Our results did not find significant $(p<0.05)$ differences between these two groups of responders (see Table 1). In addition, we compared socio-demographic variables (i.e., gender and age) using the Bonferroni test to maintain the robustness of our results. Our results indicate a similar response rate across 
subgroups, which indicates that our data is free of non-response bias (Clottey and Grawe 2014; Groves 2006).

Finally, we tested for common method bias (CMB), which is another common source of bias when using the survey method (Podsakoff et al. 2012). For this we usedmethod variance and marker variables, an approach proposed by Williams et al. (2010), to control for CMB between constructs in our model. We ran the CFA marker technique using AMOS, and the results showed no difference between the baseline model and the CFA marker model, which means that CMB does not occur in our measurements. In addition, Harman's single factor was calculated. This is a post hoc procedure conducted after data collection, in order to find out whether a single factor is accountable for variance in the data. The results of our exploratory factor analysis yielded five unique factors with eigenvalues $>1.0$ and a percentage of cumulative variance of $60.19 \%$ (Hair et al. 2018). The first extracted factor explained $26.87 \%$ of the variance, which does not put it in the in the highest category of cumulative variance (i.e. $>0.50$ ). Therefore, we conclude that CMB did not occur in this case. A summary of firms' and respondent profiles can be seen in Table 2 .

\section{$* * * * * * * * *$ PLEASE INSERT TABLE 1 HERE********* *********PLEASE INSERT TABLE 2 HERE*********}

\subsection{Measures and scales}

In survey-based studies, the measurement scales and indicators selected are key elements in producing unbiased estimates. We used measurement scales and indicators adopted from previous studies in the field of innovation and operations management to avoid scale proliferation. We considered that these indicators have been validated through test-retest and are well established (Wang and Ahmed 2004). We used multiple indicators rather than a single indicator to measure each construct in our model, which provides an advantage in capturing variances in the constructs (Hagedoorn and Cloodt 2003). This aims to reduce measurement errors and to improve the validity and reliability of indicators. In the first section of the questionnaire, we measured innovation policy (IP) using four indicators adopted from Borrás and Edquist (2013) and Edler and Fagerberg (2017). 
Respondents were asked about the innovation policies applied within their companies, including policies to support R\&D and innovation, training and skills, collaboration and networking. Furthermore, innovation strategy was measured using three indicators adopted from Wang and Ahmed (2004) and Oke et al. (2012). In this section, respondents were asked about the innovation strategies implemented within their companies. Thereafter, we measured information systems innovation using five items adopted from Strecker (2009) and Zhang et al. (2018). Respondents were asked about the use of information systems and new technology in their operational activities. We used a 7-point Likert scale to measure these constructs, ranging from 1 = "strongly disagree" to 7 = "strongly agree".

The second section of the questionnaire listed the remaining variables in our model: continuous innovation (CI), innovation performance (INP) and financial performance (CFP). Continuous innovation was measured using three items adapted from Atuahene-Gima (1996) and Strecker (2009). Respondents were asked to indicate their responses on a 7-point Likert scale, from $1=$ "not intense" to $7=$ very intense". Respondents were also asked about continuous improvements to their firm's existing products and processes. Finally, innovation performance and financial performance were respectively measured using three items adopted from Strecker (2009) and Jajja et al. (2017). Respondents were asked about the innovation performance of their firms, including growth in sales, profit and market share, as well as customer satisfaction and competitive advantage; while for financial performance, respondents were asked questions related to operating profits, return on investment and cash flow from operations.

\subsection{Data analysis}

The data analysis in this study was carried out using the structural equation modeling (SEM) approach. We applied the SEM method to simultaneously test the relationship between latent variables and perform confirmatory factor analysis (CFA). Two SEM approaches - covariance-based SEM (CB-SEM) and variance-based SEM (PLS-PM)

- are currently available to analyze such data (Jöreskog and Wold 1982). We chose CBSEM due to certain favorable considerations over PLS-SEM. First, CB-SEM enables us to test causal relationships between latent variables, where hypotheses are built from a 
theoretical foundation to produce a covariance matrix among the variables, in order to estimate the path coefficients (Jöreskog et al. 2016; Loehlin and Beaujean 2017). Second, the properties of CB-SEM make it appropriate for confirmatory research that focuses on explanations rather than predictions, and provides a variety of goodness of fit (GoF) indices including 'absolute', 'incremental', and 'parsimonious' to evaluate compatibility between the model and the data (Byrne 2016; Kline 2016). Finally, CB-SEM is a robust approach which produces stable estimates, with the benefit of some recent advances, such as providing techniques to handle non-normal data with full information maximum likelihood (FIML) and modification indices.

Given that CB-SEM follows parametric assumptions through Maximum Likelihood (ML) estimation, some basic assumptions should be fulfilled before the model estimation stage. This includes sample size, normal distributionof data, model identification and absence of collinearity among predictors in the model to obtain optimal estimation results. First, regarding the sample number requested in CB-SEM, we followed the rule of thumb provided by scholars in this field, although there is no general consensus in this case. According to Byrne (2016) and Kline (2016), the minimum sample size to estimate models in CB-SEM is more than 150, where the complexity of the model ranges from small to moderate. This is intended to obtain precise results from parameter estimates (i.e. to neither under- nor over-estimate) and to avoid the appearance of Heywood cases (i.e., negative variance) where the sample size should be larger than the number of parameters in the model. In the same vein, Loehlin and Beaujean (2017) provide sample size calculations for CB-SEM which take into account power analysis and effect size. Based on a power analysis value of 0.80 and an effect size of 0.15 , we obtained a minimum required sample size of 141 for the estimation of our model, which is fulfilled in this study. In addition, we also considered model identification by calculating the number of distinct values in the sample variance-covariance matrix as equal to or higher than the number of parameters to be estimated (Schumacker and Lomax 2016). A model is called 'identified' if the degree of freedom is equal to or greater than 1 .

Overall, the data analysis process used in this study can be divided into three key steps. First, we assessed and evaluated the results of the measurement model via CFA. 
This procedure aims to evaluate the validity of the indicators in our model (i.e., convergent validity and discriminant validity) and also to evaluate the reliability of the constructs to ensure consistency of measurements. Second, we assessed and evaluated the results of the structural model by looking at the coefficient of determination $\left(\mathrm{R}^{2}\right)$, effect size $\left(\mathrm{f}^{2}\right)$, variance inflation factor (VIF) and GoF indices and tested the proposed hypotheses using a 95\% confidence interval with 5\% (one-tailed) significance. Finally, we conducted several robustness tests in order to ensure that our analysis results are not biased; these results are presented below.

\section{Results}

We used the AMOS 25.0 software to execute our model and testing of hypotheses (Byrne 2016). AMOS is a piece of CB-SEM software that is easy to use and user-friendly. We selected some specific settings, such as the ML estimation method, and activated output options in the program. We ran the estimation model calculation and examined the first assumption in CB-SEM, namely the normality of multivariate data and the observation of freedom from outliers. Following the guidelines proposed by Byrne (2016), we evaluated the normality of data by using critical ratio (CR) values of skewness and kurtosis in the assessment of normality. The threshold value for CR of skewness should be $>3$, and $<10$ for kurtosis (Kline 2016). We obtained a kurtosis value of $4.645<10$, which indicates that the assumption of multivariate normality is fulfilled for our data. In addition, the values of $p_{1}$ and $p_{2}$ were generated from Mahalanobis d-squared $>0.05$, which indicates that our data is free from outliers. The results of the estimation model obtained are described in the following section.

\subsection{Measurement model assessment}

Before discussing the empirical findings of this study, it is pertinent to evaluate the measurement model and ensure the indicators used are valid and reliable. We evaluated the measurement model by using convergent validity, discriminant validity and construct reliability. Drawing on standard evaluation guidelines provided by several scholars (Appelbaum et al. 2018; Kline 2016; Williams et al. 2009) we used several core metrics that are commonly used in CB-SEM to report the assessment of the measurement model. 
Based on Tables 3 and 4, we obtained factor loading values for each indicator of the construct which met the limit value of $>0.70$ and average variance extracted (AVE) values > 0.50 (Bandalos 2018; Raykov and Marcoulides 2011; Schumacker and Lomax 2016). Only a few indicators yielded values slightly below this boundary, which were, nonetheless, considered acceptable according to extant guidelines for strengthening content validity (Bandalos 2018; Hair et al. 2017). We further assessed internal consistency reliability using Cronbach's alpha $(\alpha)$ and composite reliability $\left(\rho_{\mathrm{c}}\right)$. The threshold values for $\alpha$ and $\rho_{\mathrm{c}}$ are recommended to be $>0.70$. We obtained values for both measures of $>0.75$ for all constructs in the model (see Table 3 and 4); thus, the internal reliability of the constructs is satisfied. Finally, we examined GoF indices for our CFA model. As suggested by Kline (2016), we used several fit indices including the Comparative Fit Index (CFI); Incremental Index of Fit (IFI); Normed Fit Index (NFI); Tucker-Lewis Index (TLI) and Steiger-Lind Root Mean Square Error of Approximation (RMSEA). Scholars recommend the rule of thumb for CFI, IFI, NFI and TLI should be $>0.90$, while for RMSEA it should be $<0.08$. Our results meet this standard, where our CFA model obtains values of CFI $=$ $928, \mathrm{IFI}=0.919, \mathrm{TLI}=0.902$, and $\mathrm{NFI}=0.840$ and $\mathrm{RMSEA}=0.053$.

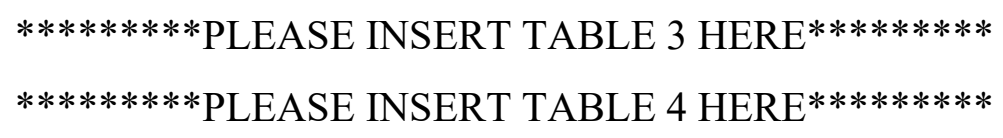

Furthermore, to assess discriminant validity, we used the Heterotrait-Monotrait (HTMT) criterion, a new approach which conceptually demonstrates the differences and similarities between the two constructs being measured. Discriminant validity confirms the measurement of two different constructs, which should measure different concepts and therefore shouldnot correlate with each other. The rule of thumb HTMT value of $>0.90$ indicates conceptually similar constructs, while HTMT values $<0.85$ indicate conceptually different constructs (Nunnally and Bernstein 1994; Franke and Sarstedt 2019). From the results in Table 5, we can see that the HTMT value is significantly lower than the specified threshold value. Therefore, discriminant validity is met for our measurements. In addition, we assessed correlations between latent constructs in the model to show the relationships 
between variables. We found the correlation between latent constructs to be positive and significant (see Table 5), which is an initial indication of the acceptance of our hypothesis.

\section{*********PLEASE INSERT TABLE 5 HERE*********}

\subsection{Detection of misspecifications model}

Following Schumacker and Lomax (2016), the first step that should be taken into account before estimating structural models is to examine the potential for model misspecifications. Although previous CFA results show that the GoF indices of this model meet the rule of thumb, we extended the scope of this test by examining the modification indices (MI) and expected parameter changes (EPC) available in AMOS outputs. We also followed the recent guidelines from Byrne (2016) and Shashi et al. (2019) and found that our model had no problems with model specification errors. We did not find EPC values $>$ 2.58 for the covariances of our model (Byrne 2016). In addition, as noted by Byrne (2016) and Maruyama (1998), the use of modification indices (MI) should only carried out when there is rigorous substantive justification via theoretical support for model respecification. As Kline (2016) argues, model respecification can cause a "capitalization on chance" problem and there are cautions to be observed around its use. To date, there have been shown to be both pros and cons in the use of modification indices in CB-SEM in general (O'Boyle et al. 2017).

\subsection{Structural model assessment}

After evaluating the measurement model, the second step was to evaluate the structural modeland test our hypotheses (see Figure 2 below). Given that CB-SEM has a large number of GoF indices, most of which depend on the sample size and complexity of the model, several scholars suggest reporting the more stable GoF indices, e.g. a combination between absolute, incremental, and parsimonious (Kline 2016; Loehlin and Beaujean 2017). We chose to report the following widely used fit indices for reasons of stability: CFI, IFI, NFI, TLI, Parsimony CFI (PCFI), Parsimony NFI (PNFI) and RMSEA. As illustrated in Table 6, we derived CFI and IFI values $>0.90$, which meet the recommended threshold (Jöreskog et al. 2016; Loehlin and Beaujean 2017). Furthermore, 
we find the NFI and TLI values to be within marginal limits. As noted by scholars of CBSEM (Kline 2016; Schumacker and Lomax 2016), these indices may be distorted due to the use of small sample sizes (e.g. 150-250). Conversely, both measures are likely to produce good fit when working with large sample sizes (i.e. above 300). In addition, we obtained values for PCFI and PNFI > 0.60, which also meet the suggested cut-off level (Byrne 2016; Kline 2016). The PCFI and PNFI indices adjust CFI and NFI through the ratio of degree of freedom between the observed model and the baseline model. Finally, we obtained an RMSEA value from the model of $0.060<0.08$, again fulfilling the minimum requirements (Schumacker and Lomax 2016).

*********PLEASE INSERT FIGURE 2 HERE*********

In addition, we also report the coefficient of determination $\left(\mathrm{R}^{2}\right)$, effect size $\left(\mathrm{f}^{2}\right)$ and variance inflation factor (VIF) (Appelbaum et al. 2018). We obtained $\mathrm{R}^{2}$ values as depicted in Table 6 for CI, INP, and CFP ranging from 0.067-0.521. According to Hair et al. (2017), these values are included in the weak to moderate category. The predictors in our model produce effect size $\left(f^{2}\right)$ values ranging from $0.019-0.347$ (i.e., falling into the small and large categories), which shows the contribution of the variance from each independent variable in the model. Finally, we obtained VIF values for each predictor in the model of $<3.3$, which indicates no high correlation or collinearity between predictor variables in our case.

\section{*********PLEASE INSERT TABLE 6 HERE**********}

\subsection{Testing of hypotheses}

In this step, we tested our hypotheses simultaneously through the model estimation calculation, and we here report the empirical findings as depicted in Table 7. We tested our hypotheses by looking at the coefficient parameter and the significant value generated from the $95 \%$ confidence intervals (CI) on the relationships between latent variables. As illustrated in Table 7, all path coefficients are significant at $p=0.05$, with 95\% CI. From these results, we conclude that all of our hypotheses are supported. Specifically, the relationships between IP $\rightarrow$ CI, INS $\rightarrow$ CI and ISI $\rightarrow$ CI were found to be 
significant, with beta $(\beta)$ values of $0.642,0.196$ and 0.061 , respectively, and significance at $p=0.000<0.01, p=0.024<0.05$ and $p=0.038<0.05$. From these results we can conclude that $\mathrm{H} 1, \mathrm{H} 2$ and $\mathrm{H} 3$ are supported. Furthermore, we found that the relationships $\mathrm{CI} \rightarrow \mathrm{INP}$ and $\mathrm{CI} \rightarrow \mathrm{CFP}$ were significant, with beta values of 0.524 and 0.111 respectively and significance at $p<0.05$. Hence, we can conclude that $\mathrm{H} 4 \mathrm{a}$ and $\mathrm{H} 4 \mathrm{~b}$ are also fully supported. Finally, we found that the relationship INP $\rightarrow$ CFP was significant, with a beta value of 0.024 and significance at $p=0.048<0.05$. Thus, $\mathrm{H} 5$ is also supported. In addition, we also ran additional analysis to test alternative models by including and excluding several variables in the model. Thus, iterative analysis was carried out to observe the changes in causal-effect relationships caused by each individual variable. The analysis results in Table 7 indicate that these alternative models fully support the results of our main analysis.

\section{*********PLEASE INSERT TABLE 7 HERE*********}

\subsection{Robustness checks}

In the final step, we performed several complementary analyses to maintain the robustness of our main results, which has become a mandatory step in reporting the results of SEM analysis (Appelbaum et al. 2018; Ketokivi and McIntosh 2017; Latan 2018). These robustness checks aim to ensure that our main results are unbiased and free of potential errors. First, we tested for endogeneity bias to ensure that there is no intervention from the omitted variables, reverse causality or other potential errors (e.g., sample-selection bias). We conducted the Heckman test using a two-step procedure. In the first step, we examined the relationships between variables without controlling for endogeneity bias. In the second step, we controlled for the effects of endogeneity bias by including a third variable in the equation. The results in Table 8 indicate that there are no differences in results either with or without controlling for this bias, which indicates that endogeneity bias does not occur in our data and model.

********* PLEASE INSERT TABLE 8 HERE $* * * * * * * * *$

Second, because our model is built on the assumption of linearity between latent variables, we tested for non-linear effects to ensure that these assumptions are fulfilled and 
that there are no quadratic effects. This is intended to fulfill the assumptions of model specification in CB-SEM (Schumacker and Lomax 2016), showing that our model has been correctly specified. We used Ramsey's regression specification error test (RESET) to assess this bias. The results of this analysis, presented in Table 9, fully support the linear relationship in our model, with a value of $p>0.05$.

********* PLEASE INSERT TABLE 9 HERE *********

Finally, we considered unobserved heterogeneity bias, which assumes that data comes from a single population. We used the finite mixture (FIMIX) method to test this bias (Ansari et al. 2000; Jedidi et al. 1997). Following the multi-method procedure provided by Sarstedt et al. (2017), we carried out the FIMIX procedure based on our sample size, with a maximum of three extracted segments. Sarstedt et al. (2017) point out that when Akaike's information criterion modified with factor $3\left(\mathrm{AIC}_{3}\right)$ and consistent Akaike's information criterion (CAIC) indicate the same number of segments, the result tends to be valid and indicates the correct number of segments. In our analysis, $\mathrm{AIC}_{3}$ and $\mathrm{CAIC}$ are both in the $\mathrm{k}=1$ segment, which is an early indication that heterogeneity does not occur in this case (see Table 10). Furthermore, we examined modified AIC with factor 4 ( $\mathrm{AIC}_{4}$ ), the Bayesian information criteria (BIC) and minimum description length with factor 5 (MDL5), which generally work better to determine the number of segments. All of these criteria show results that do not differ from previous GoF indices; therefore, we conclude that unobserved heterogeneity is not a threat to our results.

********* PLEASE INSERT TABLE 10 HERE

\section{Discussion and implications for theory and practice}

Innovation has been discussed among scholars in various fields, and the field of operations management is no exception, having been recognized as one way to enhance firm performance. This study aims to empirically test the effect of CI on firm performance by taking a sample of manufacturing companies listed on the Indonesian stock exchange. Specifically, we tested three determinants of innovation as driving factors in influencing CI, which in turn were shown to have an impact on firm performance. While a plethora of 
emerging research in the operations management field points out the pivotal role that innovation plays in enhancing firm performance, there is a lack of evidence addressing the relationship between CI and firm performance (Gunday et al. 2011; Lee et al. 2019). Our findings provide relevant contributions and answer the research calls of Kim and Chung (2017) and Jugend et al. (2018), as well as filling empirical gaps in the literature by adding preliminary evidence in the context of developing economies.

Our main findings can be summarized as follows. First, we have found evidence of a positive relationship between innovation policy (IP) and CI, whereby IP stimulates CI. That is, when there is a policy for innovation within the firm, this will encourage continuous innovation. Our findings corroborate the evidence found by innovation scholars related to policies for innovation (Rogge and Schleich 2018; Oke et al. 2012), indicating that policies related to innovation lead firms to innovate sustainably. Second, we found evidence of the important role of innovation strategies (INS) as having a positive relationship with CI. We argue that INS helps firms to identify additional customer needs and invest in R\&D in a suitable manner (Jayaram et al., 2014; Oke et al., 2012). In addition, according to Camisón and Villar-López (2014) and Zhang et al. (2018), information systems innovation (ISI) helps firms to continue to create new products and make the operational process more efficient. Therefore, both INS and ISI are expected to encourage CI in firms (Jayaram et al. 2014; Xin et al. 2010). This supports the findings of previous studies that have indicated a relationship between INS, ISI and CI (Prajogo 2016; Shi et al. 2018; Strecker 2009). Finally, we found evidence of a positive relationship between CI and firm performance, whereby CI improves innovation and financial performance. That is, companies that innovate sustainably are more likely to increase their return on investments. Our findings reinforce the evidence from previous research related to innovation and firm performance (Camisón and Villar-López 2014; Hult et al. 2004; Klingenberg et al. 2013; Wadho and Chaudhry 2018).

Our research provides a number of theoretical and practical implications as follows. In terms of theoretical implications, our study provides new insights into the operations management literature, mainly because this can be considered to be the first work to empirically test the relationship between CI and firm performance (Lichtenthaler 
2016). In addition, we have demonstrated that determinants of innovation such as IP, INS and INS can affect and improve CI. The results of this study provide the first empirical evidence of the relationships between these determinants of innovation, CI and firm performance. Moreover, these three determinants are herein jointly analyzed in a single research framework, which is a novel feature of this article. Furthermore, the characteristics of these determinants are aligned with the perspective of RBV theory, in which IP, INS and ISI constitute internal factors contributing to CI, and CI becomes a source of sustainable competitive advantage. Hence, our work supports the propositions laid out by Porter and Linde (1995), Hart (1995) and Hart and Dowell (2011), whereby CI is seen as a key element in achieving competitive advantage for the firm.

In terms of practical implications, our research results both extend the previous literature on innovation (Oke et al. 2012; Zhang et al. 2018; Koellinger 2008; Jugend et al. 2018) and provide new insights for managers about the importance of CI. Managers must make the right decisions when investing capital in CI. It must be highlighted that IP is the construct that has the most significant relationship with $\mathrm{CI}$; thus, managers should update their IP on a regular basis towards training R\&D teams in order for these teams to be able to optimally monitor the competitive landscape and propose continuous improvements to existing products and processes. In addition, managers must develop innovation performance indicators to evaluate the continuous implementation of innovation activities. As for firms, the results of this study indicate that it is important to formulate policies and innovation strategies in accordance with the continuous goals and mission of the firm. This will be crucial in facing the challenges of global competition as we approach industry 4.0 (Lopes de Sousa Jabbour et al. 2018).

\section{Limitations and future research directions}

As with all research, this study has certain limitations. First, this study does not take into account certain characteristics of firms which might influence the relationship between variables (Frank et al. 2016; Wadho and Chaudhry 2018). For example, Shi et al. (2018) indicate that firm size can influence the relationship between technological innovation and product quality. In this sense, there are significant differences between large 
and small firms in terms of resources including capital, human resources, information and technological capability to conduct R\&D and innovation. Second, our main findings may not be generalizable to other cultural contexts. Previous research has indicated that cultural factors (Efrat 2014) and democratic systems (Gao et al. 2017) have an effect on firm innovation. In addition, this study only considers firm performance in the short term, without examining long term performance using longitudinal data (Ortiz-Villajos and Sotoca 2018). Finally, this study does not consider contingency factors such as environmental uncertainty and other types of innovation, which may have effects on the relationships among variables (Gunday et al. 2011; Lee et al. 2019; Varis and Littunen 2010).

We suggest the following directions for future research. First, future research needs to consider other types of innovation, such as innovation budgeting, innovation performance indicators and innovation costing that may help to foster CI. This is a call for research to provide additional empirical evidence from other types of innovation in relation to $\mathrm{CI}$ and firm performance. Second, factors such as economic sector and country of operation, for instance, should be considered in future research as control variables in order to understand factors that may affect organizations' ability to innovate continuously, even in turbulent market environments. Finally, we encourage future research to use longitudinal data or time series that allow us to understand the effects of innovation on firm performance over time.

Acknowledgments: We thank Peter Kelle (section editor), two exceptional reviewers for their helpful comments and suggestions on prior versions of this manuscript.

\section{Conflict of Interest:}

The authors declare that they have no conflict of interest.

\section{Funding:}

The authors received no financial support for the research, authorship, and/or publication of this article.

\section{Informed Consent:}

Informed consent was obtained from all individual participants included in the study. 


\section{Appendix A. Measurement items}

\begin{tabular}{|c|c|c|c|}
\hline Construct & Code & Indicator/Item & Adapted from \\
\hline \multirow{4}{*}{$\begin{array}{l}\text { Innovation } \\
\text { Policy (IP) }\end{array}$} & IP1 & $\begin{array}{l}\text { My company has applied policies to support } \\
\text { R\&D and innovation. }\end{array}$ & \multirow{4}{*}{$\begin{array}{l}\text { Borrás and Edquist } \\
(2013) \text { and Edler and } \\
\text { Fagerberg (2017) }\end{array}$} \\
\hline & IP2 & $\begin{array}{l}\text { My company has applied policies to support } \\
\text { training and skills. }\end{array}$ & \\
\hline & IP3 & $\begin{array}{l}\text { There are policies that govern and support } \\
\text { collaboration within my company. }\end{array}$ & \\
\hline & IP4 & $\begin{array}{l}\text { My company has applied policies related to } \\
\text { networking. }\end{array}$ & \\
\hline \multirow{3}{*}{$\begin{array}{l}\text { Innovation } \\
\text { Strategy (INS) }\end{array}$} & INS1 & $\begin{array}{l}\text { We continuously try to discover additional needs } \\
\text { of our customers of which they are unaware. }\end{array}$ & \multirow{3}{*}{$\begin{array}{l}\text { Wang and Ahmed (2004), } \\
\text { Strecker (2009) and Oke } \\
\text { et al. (2012) }\end{array}$} \\
\hline & INS2 & $\begin{array}{l}\text { Our incentive system strongly encourages our } \\
\text { R\&D personnel to invent. }\end{array}$ & \\
\hline & INS3 & $\begin{array}{l}\text { In order to gain insight into the innovation } \\
\text { activities of our competitors, we are involved in } \\
\text { industry associations. }\end{array}$ & \\
\hline \multirow{6}{*}{$\begin{array}{l}\text { Information } \\
\text { Systems } \\
\text { Innovation (ISI) }\end{array}$} & IS1 & $\begin{array}{l}\text { We systematically scan for new technologies } \\
\text { inside and outside the industry. }\end{array}$ & \multirow{6}{*}{$\begin{array}{l}\text { Strecker (2009) and } \\
\text { Zhang et al. (2018) }\end{array}$} \\
\hline & IS2 & $\begin{array}{l}\text { The majority of our innovations use new } \\
\text { technology and information systems that permit } \\
\text { quantum leaps in performance. }\end{array}$ & \\
\hline & IS3 & The majority of our innovations use technologies & \\
\hline & & $\begin{array}{l}\text { or cause significant changes in the whole } \\
\text { industry. }\end{array}$ & \\
\hline & IS4 & $\begin{array}{l}\text { Technological and information systems } \\
\text { developments are of the highest priority for our } \\
\text { top executives. }\end{array}$ & \\
\hline & IS5 & $\begin{array}{l}\text { Overall, our firm's innovation portfolio is } \\
\text { successful in enabling us to get into new } \\
\text { technologies for our business. }\end{array}$ & \\
\hline
\end{tabular}




\begin{tabular}{|c|c|c|c|}
\hline Construct & Code & Indicator/Item & Adapted from \\
\hline \multirow{3}{*}{$\begin{array}{c}\text { Continuous } \\
\text { Innovation (CI) }\end{array}$} & CI1 & $\begin{array}{l}\text { My company makes continuous efforts to re- } \\
\text { invent the firm's products and processes. }\end{array}$ & \multirow{3}{*}{$\begin{array}{l}\text { Atuahene-Gima (1996) } \\
\text { and Strecker (2009) }\end{array}$} \\
\hline & $\mathrm{CI} 2$ & $\begin{array}{l}\text { My company strives to make continuous } \\
\text { improvements to existing products and } \\
\text { processes. }\end{array}$ & \\
\hline & $\mathrm{CI} 3$ & $\begin{array}{l}\text { My company has experienced a continuous } \\
\text { growth rate in terms of patents over the last three } \\
\text { years. }\end{array}$ & \\
\hline \multirow{3}{*}{$\begin{array}{l}\text { Innovation } \\
\text { Performance } \\
\quad \text { (INP) }\end{array}$} & INP1 & $\begin{array}{l}\text { Our profits, sales and market sharefrom new } \\
\text { products have been high, compared to our } \\
\text { competitors. }\end{array}$ & \multirow{3}{*}{$\begin{array}{l}\text { Strecker (2009) and Jajja } \\
\text { et al. (2017) }\end{array}$} \\
\hline & INP2 & $\begin{array}{l}\text { Compared to the competition, our product } \\
\text { innovations enhance customer satisfaction and } \\
\text { competitive advantage. }\end{array}$ & \\
\hline & INP3 & $\begin{array}{l}\text { Overall, our new product success rate is good } \\
\text { compared to our major competitors (in terms of } \\
\text { costs and cycle time). }\end{array}$ & \\
\hline \multirow{3}{*}{$\begin{array}{l}\text { Financial } \\
\text { Performance } \\
\quad(\text { CFP })\end{array}$} & FP1 & $\begin{array}{l}\text { The operating profits of our company are high } \\
\text { compared to our competitors. }\end{array}$ & \multirow{3}{*}{$\begin{array}{l}\text { Strecker (2009) and Jajja } \\
\text { et al. (2017) }\end{array}$} \\
\hline & FP2 & $\begin{array}{l}\text { The return on investment (ROI) of our company } \\
\text { is high compared to our competitors. }\end{array}$ & \\
\hline & FP3 & $\begin{array}{l}\text { Our growth in terms of cash flow from } \\
\text { operations has been high, relative to the } \\
\text { competition. }\end{array}$ & \\
\hline
\end{tabular}

\section{References}

Allen, J. P. (2000). Information systems as technological innovation. Information Technology \& People, 13(2), 210-221.

Anandarajan, A., Chin, C.-L., Chi, H.-Y., \& Lee, P. (2007). The effect of innovative activity on firm performance: The experience of Taiwan. Advances in Accounting, $23,1-30$.

Ansari, A., Jedidi, K., \& Jagpal, H. S. (2000). A hierarchical bayesian methodology for treating heterogeneity in structural equation models. Marketing Science, 19(4), 328347. 
Appelbaum, M., Cooper, H., Kline, R. B., Mayo-Wilson, E., Nezu, A. M., \& Rao, S. M. (2018). Journal article reporting standards for quantitative research in psychology: The APA publications and communications board task force report. American Psychologist, 73(1), 3-25.

Atuahene-Gima, K. (1996). Differential potency of factors affecting innovation performance in manufacturing and services firms in Australia. Journal of Product Innovation Management, 13(1), 35-52.

Aubert, J.-E. (2018). Rwanda's innovation challenges and policies - lessons for Africa. Journal of Intellectual Capital, 19(3), 550-561.

Azadegan, A., \& Dooley, K. J. (2010). Supplier innovativeness, organizational learning styles and manufacturer performance: An empirical assessment. Journal of Operations Management, 28, 488-505.

Bandalos, D. L. (2018). Measurement theory and applications for the social sciences. New York: Guilford Press.

Barney, J. (1991). Firm resources and sustained competitive advantage. Journal of Management, 17, 771-792.

Baruch, Y., \& Holtom, B. C. (2008). Survey response rate levels and trends in organizational research. Human Relations, 61(8), 1139-1160.

Bates, K. A., \& Flynn, E. J. (1995). Innovation history and competitive advantage: A resource-based view analysis of manufacturing technology innovations. Academy of Management Proceedings, 1, 235-239.

Becheikh, N., Landry, R., \& Amara, N. (2006). Lessons from innovation empirical studies in the manufacturing sector: A systematic review of the literature from 1993-2003. Technovation, 26(5/6), 644-664.

Bigliardi, B. (2013). The effect of innovation on financial performance: A research study involving SMEs. Innovation, 15(2), 245-255.

Boer, H., Caffyn, S., Corso, M., Coughlan, P., Gieskes, J., Magnusson, M., et al. (2001). Knowledge and continuous innovation: The CIMA methodology. International Journal of Operations \& Production Management, 21(4), 573-591.

Boer, H., \& During, W. E. (2001). Innovation, what innovation? A comparison between product, process and organizational innovation. International Journal of Technology Management, 22, 83-107.

Borrás, S., \& Edquist, C. (2013). The choice of innovation policy instruments. Technological Forecasting \& Social Change, 80, 1513-1522.

Byrne, B. M. (2016). Structural equation modeling with AMOS: Basic concepts, applications, and programming (3rd ed.). New York: Routledge.

Camisón, C., \& Villar-López, A. (2014). Organizational innovation as an enabler of technological innovation capabilities and firm performance. Journal of Business Research, 67, 2891-2902.

Caridi, M., Pero, M., \& Sianesi, A. (2012). Linking product modularity and innovativeness to supply chain management in the Italian furniture industry. International Journal of Production and Economics, 136, 207-217.

Černe, M., Jaklič, M., \& Škerlavaj, M. (2015). Management innovation enters the game: Reconsidering the link between technological innovation and financial performance. Innovation, 17(4), 429-449. 
Cheng, C.-F., Lai, M.-K., \& Wu, W.-Y. (2010). Exploring the impact of innovation strategy on R\&D employees' job satisfaction: A mathematical model and empirical research. Technovation, 30, 459-470.

Chou, Y.-C., Chuang, H. H.-C., \& Shao, B. B. M. (2014). The impacts of information technology on total factor productivity: A look at externalities and innovations. International Journal of Production and Economics, 158, 290-299.

Clottey, T. A., \& Grawe, S. J. (2014). Non-response bias assessment in logistics survey research: use fewer tests? International Journal of Physical Distribution \& Logistics Management, 44(5), 412-426.

Costantini, V., Crespi, F., \& Palma, A. (2017). Characterizing the policy mix and its impact on eco-innovation: A patent analysis of energy-efficient technologies. Research Policy, 46, 799-819.

Crossan, M. M., \& Apaydin, M. (2010). A multi-dimensional framework of organizational innovation: A systematic review of the literature. Journal of management studies, 47(6), 1154-1191.

Dalecki, M. G., Whitehead, J. C., \& Blomquist, G. C. (1993). Sample non-response bias and aggregate benefits in contingent valuation: An examination of early, late and non-respondents. Journal of Environmental Management, 38(2), 133-143.

Dillman, D. A., Smyth, J. D., \& Christian, L. M. (2014). Internet, phone, mail, and mixed mode surveys: The tailored design method (4th ed.). Hoboken, NJ: Wiley.

Edler, J., \& Fagerberg, J. (2017). Innovation policy: what, why, and how. Oxford Review of Economic Policy, 33(1), 2-23.

Efrat, K. (2014). The direct and indirect impact of culture on innovation. Technovation, 34, 12-20.

Escrig-Tena, A. B., Segarra-Cipres, M., García-Juan, B., \& Beltran-Martín, I. (2018). The impact of hard and soft quality management and proactive behaviour in determining innovation performance. International Journal of Production and Economics, 200, $1-14$.

Fabrizio, K. R., Poczter, S., \& Zelner, B. A. (2017). Does innovation policy attract international competition? Evidence from energy storage. Research Policy, 46, $1106-1117$.

Ferro de Guimarães, J. C., Severo, E. A., Dorion, E. C. H., Coallier, F., \& Olea, P. M. (2016). The use of organisational resources for product innovation and organisational performance: A survey of the Brazilian furniture industry. International Journal of Production and Economics, 180, 135-147.

Forza, C. (2002). Survey research in operations management: a process-based perspective. International Journal of Operations \& Production Management, 22(2), 152-194.

Fowler Jr, F. J. (2013). Survey research methods (5th ed.). Thousand Oaks: Sage Publications.

Frank, A. G., Cortimiglia, M. N., Ribeiro, J. L. D., \& Oliveira, L. S. d. (2016). The effect of innovation activities on innovation outputs in the Brazilian industry: Marketorientation vs. technology-acquisition strategies. Research Policy, 45, 577-592.

Franke, G., \& Sarstedt, M. (2019). Heuristics versus statistics in discriminant validity testing: A comparison of four procedures. Internet Research, 29(3), 430-447. 
Galende, J., \& de la Fuente, J. M. (2003). Internal factors determining a firm's innovative behaviour. Research Policy, 32(5), 715-736.

Gao, Y., Zang, L., Roth, A., \& Wang, P. (2017). Does democracy cause innovation? An empirical test of the popper hypothesis. Research Policy, 46, 1272-1283.

García-Zamora, E., González-Benito, Ó., \& Muñoz-Gallego, P. A. (2013). Organizational and environmental factors as moderators of the relationship between multidimensional innovation and performance. Innovation, 15(2), 224-244.

Groves, R. M. (2006). Nonresponse rates and nonresponse bias in household surveys. The Public Opinion Quarterly, 70(5), 646-675.

Groves, R. M., Fowler Jr, F. J., Couper, M. P., Lepkowski, J. M., Singer, E., \& Tourangeau, R. (2009). Survey methodology (2nd ed.). New York: Wiley.

Gunday, G., Ulusoy, G., Kilic, K., \& Alpkan, L. (2011). Effects of innovation types on firm performance. International Journal of Production and Economics, 133, 662-676.

Gupta, S., Malhotra, N. K., Czinkota, M., \& Foroudi, P. (2016). Marketing innovation: A consequence of competitiveness. Journal of Business Research, 69, 5671-5681.

Hagedoorn, J., \& Cloodt, M. (2003). Measuring innovative performance: is there an advantage in using multiple indicators? Research Policy, 32, 1365-1379.

Hair, J. F., Babin, B. J., Anderson, R. E., \& Black, W. C. (2018). Multivariate data analysis (8th ed.). Mason, Ohio: Cengage Learning.

Hair, J. F., Hult, G. T. M., Ringle, C. M., \& Sarstedt, M. (2017). A Primer on partial least squares structural equation modeling (PLS-SEM) (2nd ed.). Thousand Oaks: Sage Publications.

Hart, S. L. (1995). A natural-resource-based view of the firm. Academy of Management Review, 20, 986-1014.

Hart, S. L., \& Dowell, G. (2011). A natural-resource-based view of the firm: Fifteen years after. Journal of Management, 37(5), 1464-1479.

Huang, Y.-F., \& Chen, C.-J. (2010). The impact of technological diversity and organizational slack on innovation. Technovation, 30, 420-428.

Hult, G. T. M., Hurley, R. F., \& Knight, G. A. (2004). Innovativeness: Its antecedents and impact on business performance. Industrial Marketing Management, 33, 429-438.

Jackson, S. A., Gopalakrishna-Remani, V., Mishra, R., \& Napier, R. (2016). Examining the impact of design for environment and the mediating effect of quality management innovation on firm performance. International Journal of Production and Economics, 173, 142-152.

Jajja, M. S. S., Kannan, V. R., Brah, S. A., \& Hassan, S. Z. (2017). Linkages between firm innovation strategy, suppliers, product innovation, and business performance: Insights from resource dependence theory. International Journal of Operations \& Production Management, 37(8), 1054-1075.

Jayaram, J., Oke, A., \& Prajogo, D. (2014). The antecedents and consequences of product and process innovation strategy implementation in Australian manufacturing firms. International Journal of Production Research, 52, 4424-4439.

Jedidi, K., Jagpal, H. S., \& DeSarbo, W. S. (1997). Finite-mixture structural equation models for response-based segmentation and unobserved heterogeneity. Marketing Science, 16(1), 39-59. 
Jöreskog, K. G., Olsson, U. H., \& Wallentin, F. Y. (2016). Multivariate analysis with LISREL. Switzerland: Springer International Publishing.

Jöreskog, K. G., \& Wold, H. (1982). The ML and PLS techniques for modeling with latent variables: Historical and comparative aspects. In K. G. Jöreskog, \& H. Wold (Eds.), Systems under indirect observation: Causality, structure, prediction (Vol. 1, pp. 263-270). Amsterdam: North Holland.

Joshi, K. D., Chi, L., Datta, A., \& Han, S. (2010). Changing the competitive landscape: Continuous innovation through IT-enabled knowledge capabilities. Information Systems Research, 21(3), 472-495.

Jugend, D., Chiappeta Jabbour, C. J., Scaliza, J. A. A., Rocha, R. S., Gobbo, J. A., Latan, H., et al. (2018). Relationships among open innovation, innovative performance, government support and firm size: Comparing Brazilian firms embracing different levels of radicalism in innovation. Technovation, 74, 54-65.

Kamasak, R. (2015). Determinants of innovation performance: A resource-based study. Procedia Social and Behavioral Sciences, 195, 1330-1337.

Ketokivi, M., \& McIntosh, C. N. (2017). Addressing the endogeneity dilemma in operations management research: Theoretical, empirical, and pragmatic considerations. Journal of Operations Management, 52, 1-14.

Kim, J. S., \& Chung, G. H. (2017). Implementing innovations within organizations: A systematic review and research agenda. Innovation, 19(3), 372-399.

Kline, R. B. (2016). Principles and practice of structural equation modeling (4th ed.). New York: Gulford Press.

Klingenberg, B., Timberlake, R., Geurts, T. G., \& Brown, R. J. (2013). The relationship of operational innovation and financial performance - A critical perspective. International Journal of Production and Economics, 142, 317-323.

Koellinger, P. (2008). The relationship between technology, innovation, and firm performance-Empirical evidence from e-business in Europe. Research Policy, 37, 1317-1328.

Kostopoulos, K. C., Spanos, Y. E., \& Prastacos, G. P. (2002). The resource-based view of the firm and innovation: identification of critical linkages. Paper presented at the The 2nd European Academy of Management Conference

Latan, H. (2018). PLS path modeling in hospitality and tourism research: The golden age and days of future past. In F. Ali, S. M. Rasoolimanesh, \& C. Cobanoglu (Eds.), Applying partial least squares in tourism and hospitality research (pp. 53-83). Bingley: Emerald.

Lee, R., Lee, J.-H., \& Garrett, T. C. (2019). Synergy effects of innovation on firm performance. Journal of Business Research, doi:doi.org/10.1016/j.jbusres.2017.08.032.

Lianto, B., Dachyar, M., \& Soemardi, T. P. (2018). Continuous innovation: a literature review and future perspective. International Journal on Advanced Science, Engineering and Information Technology, 8(3), 771-779.

Lichtenthaler, U. (2016). Toward an innovation-based perspective on company performance. Management Decision, 54(1), 66-87. 
Lii, P., \& Kuo, F.-I. (2016). Innovation-oriented supply chain integration for combined competitiveness and firm performance. International Journal of Production and Economics, 174, 142-155.

Liu, X., \& Wu, X. (2011). Technology embeddedness, innovation differentiation strategies and firm performance: Evidence from Chinese manufacturing firms. Innovation, 13(1), 20-35.

Loehlin, J. C., \& Beaujean, A. A. (2017). Latent variable models: An introduction to factor, path, and structural equation analysis (5th ed.). New York: Routledge.

Lopes de Sousa Jabbour, A. B., Chiappetta Jabbour, C. J., Foropon, C., \& Filho, M. G. (2018). When titans meet - Can industry 4.0 revolutionise the environmentally sustainable manufacturing wave? The role of critical success factors. Technological Forecasting \& Social Change, 132, 18-25.

Ma, L., Zhai, X., Zhong, W., \& Zhang, Z.-X. (2019). Deploying human capital for innovation: A study of multi-country manufacturing firms. International Journal of Production and Economics, 208, 241-253.

Manjón, J. V. G., \& Merino, E. R. (2012). Innovation systems and policy design: The European experience. Innovation, 14(1), 33-42.

Manzani, Y. E., Sidmou, M. L., \& Cegarra, J. J. (2019). Does IS0 9001 quality management system support product innovation? An analysis from the sociotechnical systems theory. International Journal of Quality \& Reliability Management, 36(6), 951-982.

Maruyama, G. M. (1998). Basics of structural equation modeling. Thousand Oaks: Sage Publications.

Melville, N. P. (2010). Information systems innovation for environmental sustainability. MIS Quarterly, 34, 1-21.

Naranjo-Valencia, J. C., Jimenez-Jimenez, D., \& Sanz-Valle, R. (2011). Innovation or imitation? The role of organizational culture. Management Decision, 49(1), 55-72.

Nunnally, J. C., \& Bernstein, I. H. (1994). Psychometric theory (3rd ed.). New York: McGraw-Hill.

O'Boyle, E. H., Banks, G. C., \& Gonzalez-Mulé, E. (2017). The chrysalis effect: How ugly initial results metamorphosize into beautiful articles. Journal of Management, 43(2), 376-399.

Oke, A., Walumbwa, F. O., \& Myers, A. (2012). Innovation strategy, human resource policy, and firms' revenue growth: The roles of environmental uncertainty and innovation performance. Decision Sciences, 43(2), 273-302.

Ortiz-Villajos, J. M., \& Sotoca, S. (2018). Innovation and business survival: A long-term approach. Research Policy, 47, 1418-1436.

Podsakoff, P. M., MacKenzie, S. B., \& Podsakoff, N. P. (2012). Sources of method bias in social science research and recommendations on how to control it. Annual Review of Psychology, 63(4), 539-569.

Porter, M. E., \& Linde, C. v. d. (1995). Toward a new conception of the environmentcompetitiveness relationship. Journal of Economic Perspectives, 9(4), 97-118.

Prajogo, D. I. (2016). The strategic fit between innovation strategies and business environment in delivering business performance. International Journal of Production and Economics, 171, 241-249. 
Raykov, T., \& Marcoulides, G. A. (2011). Introduction to psychometric theory. New York: Routledge.

Resende, M., Strube, E., \& Zeidan, R. (2014). Complementarity of innovation policies in Brazilian industry: An econometric study. International Journal of Production and Economics, 158, 9-17.

Rogge, K. S., \& Schleich, J. (2018). Do policy mix characteristics matter for low-carbon innovation? A survey based exploration of renewable power generation technologies in Germany. Research Policy, 47, 1639-1654.

Rossiter, J. R. (2011). Measurement for the social sciences: The C-OAR-SE method and why it must replace psychometrics. New York: Spinger.

Rossiter, J. R. (2013). Scientific progress in measurement theory? AMS Review, 3(1), 171179.

Russo, M. V., \& Fouts, P. A. (1997). A resource-based perspective on corporate environmental performance and profitability. Academy of Management Journal, 40(3), 534-559.

Sarstedt, M., Ringle, C. M., \& Hair, J. F. (2017). Treating unobserved heterogeneity in PLS-SEM: A multi-method approach In H. Latan, \& R. Noonan (Eds.), Partial least squares path modeling: Basic concepts, methodological issues, and applications (pp. 197-217). Cham: Springer International.

Schumacker, R. E., \& Lomax, R. G. (2016). A beginner's guide to structural equation modeling (4th ed.). New York: Routledge.

Shao, B. B. M., \& Lin, W. T. (2016). Assessing output performance of information technology service industries: Productivity, innovation and catch-up. International Journal of Production and Economics, 172, 43-53.

Shashi, Centobelli, P., Cerchione, R., \& Singh, R. (2019). The impact of leanness and innovativeness on environmental and financial performance: Insights from Indian SMEs. International Journal of Production and Economics, doi:10.1016/j.ijpe.2019.02.011.

Shi, L., Lin, W., Chen, P. K., \& Su, C. H. (2019). How can the ISO 9000 QMS improve the organizational innovation of supply chains? International Journal of Innovation Science, 11(2), 278-298.

Shi, L., Wang, X., Sun, H., \& He, Z. (2018). The impact of technological innovation on product quality: The moderating role of firm size. Total Quality Management \& Business Excellence, 29, 746-761.

Simpson, P. M., Siguaw, J. A., \& Enz, C. A. (2006). Innovation orientation outcomes: The good and the bad. Journal of Business Research, 59, 1133-1141.

Steiber, A., \& Alänge, S. (2013). A corporate system for continuous innovation: the case of Google Inc. European Journal of Innovation Management, 16(2), 243-264.

Strecker, N. (2009). Innovation strategy and firm performance: An empirical study of publicly listed firms. Wiesbaden GmbH: Gabler Verlag.

Terziovski, M., \& Guerrero, J.-L. (2014). ISO 9000 quality system certification and its impact on product and process innovation performance. International Journal of Production and Economics, 158, 197-207. 
Terziovski, M., \& Sohal, A. S. (2000). The adoption of continuous improvement and innovation strategies in Australian manufacturing firms. Technovation, 20, 539550.

Varis, M., \& Littunen, H. (2010). Types of innovation, sources of information and performance in entrepreneurial SMEs. European Journal of Innovation Management, 13(2), 128-154.

Wadho, W., \& Chaudhry, A. (2018). Innovation and firm performance in developing countries: The case of Pakistani textile and apparel manufacturers. Research Policy, 47, 1283-1294.

Wang, C. L., \& Ahmed, P. K. (2004). The development and validation of the organisational innovativeness construct using confirmatory factor analysis. European Journal of Innovation Management, 7(4), 303-313.

Williams, L. J., Hartman, N., \& Cavazotte, F. (2010). Method variance and marker variables: A review and comprehensive CFA marker technique. Organizational Research Methods, 13(3), 477-514.

Williams, L. J., Vandenberg, R. J., \& Edwards, J. R. (2009). Structural equation modeling in management research: A guide for improved analysis. The Academy of Management Annals, 3(1), 543-604.

Xin, J. Y., Yeung, A. C. L., \& Cheng, T. C. E. (2010). First to market: Is technological innovation in new product development profitable in health care industries? International Journal of Production and Economics, 127, 129-135.

Zhang, M., Zhao, X., \& Lyles, M. (2018). Effects of absorptive capacity, trust and information systems on product innovation. International Journal of Operations \& Production Management, 38(2), 493-512. 


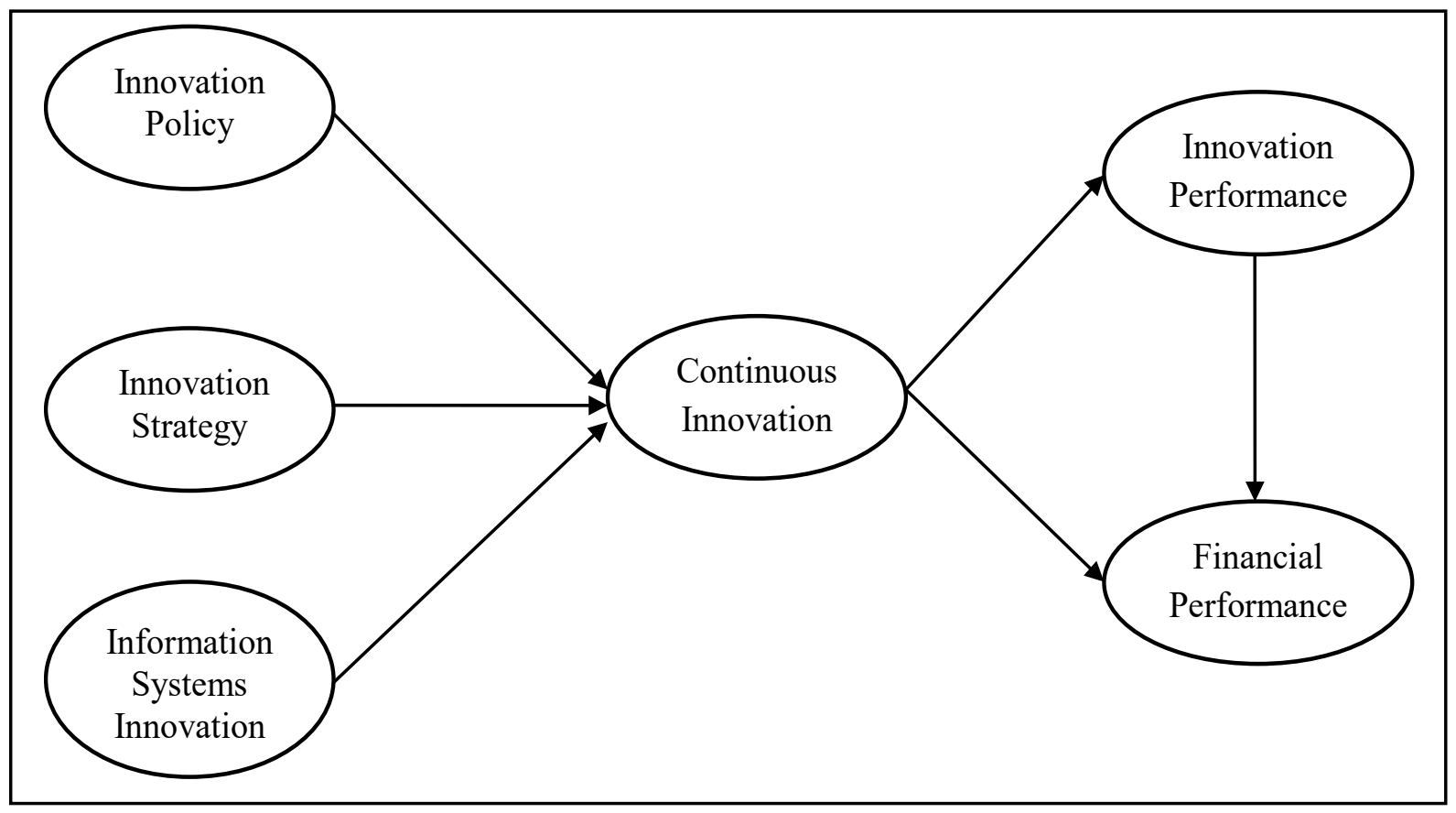

Fig.1. Conceptual model and relationships among variables

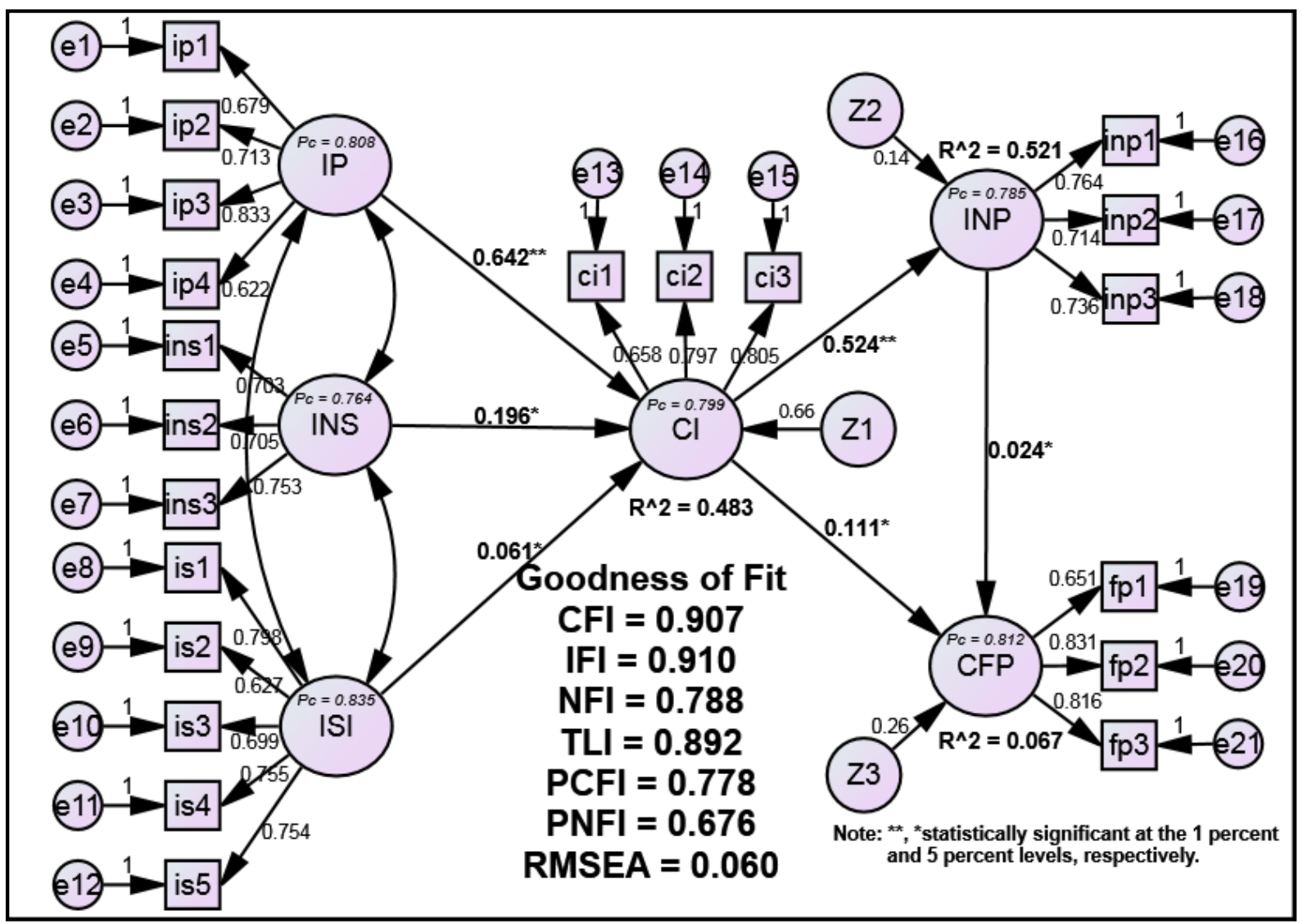

Fig.2. Evaluation of the measurement and structural models 
Table 1

Assessment of Principal Component Analysis (PCA) and Non-Response Bias

\begin{tabular}{l|cccc}
\hline \multicolumn{1}{c|}{ Construct } & $\begin{array}{c}\mathbf{F L} \\
(\boldsymbol{n}=\mathbf{4 2})\end{array}$ & $\begin{array}{c}\boldsymbol{\alpha} \\
(\boldsymbol{n}=\mathbf{4 2})\end{array}$ & $\begin{array}{c}\text { Sig. Levene's } \\
\text { Test }\end{array}$ & $\begin{array}{c}\text { Sig. t-test for } \\
\text { Equality of Means }\end{array}$ \\
\hline Innovation Policy (IP) & $0.542-0.876$ & 0.747 & 0.782 & 0.484 \\
Innovation Strategy (INS) & $0.686-0.832$ & 0.664 & 0.815 & 0.937 \\
Information Systems Innovation (ISI) & $0.591-0.929$ & 0.723 & 0.551 & 0.223 \\
Continuous Innovation (CI) & $0.720-0.800$ & 0.631 & 0.463 & 0.660 \\
Innovation Performance (INP) & $0.828-0.846$ & 0.777 & 0.167 & 0.892 \\
Financial Performance (CFP) & $0.788-0.897$ & 0.818 & 0.612 & 0.506 \\
\hline
\end{tabular}

Note: FL is Factor loading; $\alpha=$ Cronbach's alpha.

Table 2

Profile of Firms and Respondents

\begin{tabular}{|c|c|c|c|c|c|}
\hline Category & Frequency & $\begin{array}{c}\text { Percentage } \\
(\%)\end{array}$ & $\begin{array}{c}\text { Demographic } \\
\text { variable }\end{array}$ & Frequency & $\begin{array}{c}\text { Percentage } \\
(\%)\end{array}$ \\
\hline Employees & & & Gender & & \\
\hline$<250$ & 14 & 7.53 & Male & 147 & 79.03 \\
\hline $250-300$ & 28 & 15.05 & Female & 39 & 20.97 \\
\hline $301-500$ & 37 & 19.89 & & & \\
\hline $501-1000$ & 48 & 25.81 & Age (years) & & \\
\hline \multirow[t]{2}{*}{$>1000$} & 59 & 31.72 & $30-40$ & 36 & 19.36 \\
\hline & & & $41-50$ & 74 & 39.78 \\
\hline Sales Volume & & & $51-60$ & 53 & 28.49 \\
\hline$<50$ billion IDR & 16 & 8.60 & $>60$ & 23 & 12.37 \\
\hline $51-70$ billion IDR & 31 & 16.67 & & & \\
\hline $71-100$ billion IDR & 63 & 33.87 & Work experience & & \\
\hline $101-200$ billion IDR & 54 & 29.03 & $1-7$ years & 38 & 20.43 \\
\hline \multirow[t]{2}{*}{$>200$ billion IDR } & 22 & 11.83 & $8-15$ years & 88 & 47.31 \\
\hline & & & $16-25$ years & 54 & 29.03 \\
\hline Industry & & & Over 25 years & 6 & 3.23 \\
\hline Food and beverages & 42 & 22.58 & & & \\
\hline Textile & 24 & 12.90 & Level of education & & \\
\hline Paper & 17 & 9.14 & Bachelor's degree & 35 & 18.82 \\
\hline Chemical & 30 & 16.13 & Master's degree & 84 & 45.16 \\
\hline Metal products & 27 & 14.52 & Doctorate degree & 67 & 36.02 \\
\hline Machinery and equipment & 33 & 17.74 & & & \\
\hline Other manufacturing & 13 & 6.99 & & & \\
\hline
\end{tabular}


Table 3

Measurement Model Assessment of Innovation Policy, Innovation Strategy and

Information Systems Innovation

\begin{tabular}{|c|c|c|c|c|c|c|c|}
\hline Indicator/Item & Code & Mean & S.D & FL & AVE & $\alpha$ & $\rho_{c}$ \\
\hline A) Innovation Policy (IP) & & & & & 0.516 & 0.804 & 0.808 \\
\hline Policies to support $\mathrm{R} \& \mathrm{D}$ and innovation & IP1 & 4.687 & 1.616 & 0.690 & & & \\
\hline Policies to support training and skills & IP2 & 5.133 & 1.782 & 0.713 & & & \\
\hline Policies to support collaboration & IP3 & 4.627 & 1.825 & 0.833 & & & \\
\hline Innovation network policies & IP4 & 4.843 & 1.753 & 0.622 & & & \\
\hline B) Innovation Strategy (INS) & & & & & 0.519 & 0.759 & 0.764 \\
\hline Discovering additional needs of customers & INS1 & 4.602 & 1.907 & 0.703 & & & \\
\hline $\begin{array}{l}\text { Incentive system for encouraging } \mathrm{R} \& \mathrm{D} \\
\text { innovation }\end{array}$ & INS2 & 4.265 & 1.905 & 0.705 & & & \\
\hline $\begin{array}{l}\text { Gaining insight into the innovation activities of } \\
\text { competitors }\end{array}$ & INS3 & 5.241 & 1.834 & 0.753 & & & \\
\hline C) Information Systems Innovation (ISI) & & & & & 0.504 & 0.818 & 0.835 \\
\hline $\begin{array}{l}\text { Systematically searching for new technologies } \\
\text { and information systems }\end{array}$ & IS1 & 4.602 & 2.359 & 0.708 & & & \\
\hline $\begin{array}{l}\text { Using new technology and information systems } \\
\text { that permit quantum leaps in performance }\end{array}$ & IS2 & 4.247 & 2.348 & 0.627 & & & \\
\hline $\begin{array}{l}\text { Using technologies and information systems that } \\
\text { have an impact on or cause significant } \\
\text { changes }\end{array}$ & IS3 & 2.350 & 1.897 & 0.699 & & & \\
\hline $\begin{array}{l}\text { Technological and information systems } \\
\text { developments as a high priority for top } \\
\text { executives }\end{array}$ & IS4 & 4.795 & 2.348 & 0.755 & & & \\
\hline $\begin{array}{c}\text { The firm's innovation portfolio enabling the use } \\
\text { of new technologies and information systems }\end{array}$ & IS5 & 3.482 & 2.512 & 0.754 & & & \\
\hline
\end{tabular}

Note: FL is Factor loading; S.D. is Standard deviation; AVE $=$ Average variance extracted; $\alpha=$ Cronbach's alpha; $\rho_{c}=$ Composite reliability. 
Table 4

Measurement Model Assessment of Continuous Innovation and Firm Performance

\begin{tabular}{|c|c|c|c|c|c|c|c|}
\hline Indicator/Item & Code & Mean & S.D & FL & AVE & $\alpha$ & $\rho_{c}$ \\
\hline Continuous Innovation (CI) & & & & & 0.572 & 0.755 & 0.799 \\
\hline $\begin{array}{l}\text { Continuous efforts to re-invent the firm's products } \\
\text { and processes }\end{array}$ & CI1 & 4.127 & 1.719 & 0.658 & & & \\
\hline $\begin{array}{l}\text { Continuous improvements to existing products and } \\
\text { processes }\end{array}$ & $\mathrm{CI} 2$ & 4.416 & 1.175 & 0.797 & & & \\
\hline $\begin{array}{l}\text { Continuous growth rate of patents over the last three } \\
\text { years }\end{array}$ & $\mathrm{CI} 3$ & 4.325 & 1.750 & 0.805 & & & \\
\hline Innovation Performance (INP) & & & & & 0.550 & 0.766 & 0.785 \\
\hline $\begin{array}{l}\text { High growth in sales, profit and market share relative } \\
\text { to competitors }\end{array}$ & INP1 & 3.331 & 1.239 & 0.764 & & & \\
\hline $\begin{array}{l}\text { Customer satisfaction and competitive advantage } \\
\text { increased by product innovations }\end{array}$ & INP2 & 3.602 & 0.987 & 0.714 & & & \\
\hline $\begin{array}{l}\text { Overall, new product success is good compared to } \\
\text { major competitors (in terms of costs and cycle } \\
\text { time) }\end{array}$ & INP3 & 3.849 & 1.220 & 0.736 & & & \\
\hline Financial Performance (CFP) & & & & & 0.593 & 0.790 & 0.812 \\
\hline Operating profits & FP1 & 3.078 & 0.957 & 0.651 & & & \\
\hline Return on investment (ROI) & FP2 & 3.373 & 0.997 & 0.831 & & & \\
\hline Cash flow from operations & FP3 & 3.199 & 0.852 & 0.816 & & & \\
\hline
\end{tabular}

Note: FL is Factor loading; S.D. is Standard deviation; AVE = Average variance extracted; $\alpha=$ Cronbach's alpha; $\rho_{c}=$ Composite reliability. 
Table 5

Assessment of Discriminant Validity using the HTMT

\begin{tabular}{|c|c|c|c|c|c|c|}
\hline Construct & 1 & 2 & 3 & 4 & 5 & 6 \\
\hline Continuous Innovation (CI) & $(0.900)$ & $0.394 * *$ & $0.299 * *$ & $0.640 * *$ & $0.539 * *$ & $0.370 * *$ \\
\hline Financial Performance (CFP) & $0.246[0.125 ; 400]$ & $(0.900)$ & $0.331 * *$ & $0.401 * *$ & $0.262 * *$ & $0.296^{* *}$ \\
\hline Information Systems Innovation (ISI) & $0.348[0.221 ; 494]$ & $0.189[0.095 ; 259]$ & (0.900) & $0.462 * *$ & $0.371 * *$ & $0.353 * *$ \\
\hline Innovation Performance (INP) & $0.762[0.663 ; 851]$ & $0.285[0.150 ; 441]$ & $0.359[0.220 ; 485]$ & (0.900) & $0.357 * *$ & $0.351 * *$ \\
\hline Innovation Policy (IP) & $0.709[0.573 ; 822]$ & $0.359[0.221 ; 491]$ & $0.363[0.222 ; 492]$ & $0.483[0.337 ; 611]$ & $(0.900)$ & $0.326^{* *}$ \\
\hline Innovation Strategy (INS) & $0.484[0.316 ; 622]$ & $0.132[0.051 ; 202]$ & $0.458[0.324 ; 587]$ & $0.469[0.318 ; 597]$ & $0.427[0.262 ; 573]$ & $(0.900)$ \\
\hline
\end{tabular}

Note: brackets show the lower and upper bounds of the $95 \%$ BCa confidence intervals. Above the diagonal elements are the correlations between the construct. $* *$ Correlation is significant at the 0.05 level (2-tailed). 
Table 6

Structural Model Assessment

\begin{tabular}{l|cccccc}
\multicolumn{1}{c|}{ Construct } & $\mathbf{R}^{\mathbf{2}}$ & $\boldsymbol{f}^{\mathbf{2}}$ & VIF & GoF & \multicolumn{2}{c}{ Cut-off } \\
\hline Innovation Policy (IP) & - & 0.242 & 1.236 & CFI $=0.907$ & Fit \\
Innovation Strategy (INS) & - & 0.049 & 1.264 & IFI $=0.910$ & Fit \\
Information Systems Innovation (ISI) & - & 0.066 & 1.175 & NFI $=0.788$ & Marginal \\
Continuous Innovation (CI) & 0.483 & $0.026-0.347$ & 1.694 & TLI $=0.892$ & Marginal \\
Innovation Performance (INP) & 0.521 & 0.019 & 1.694 & PCFI $=0.778$ & Fit \\
Financial Performance (CFP) & 0.067 & - & - & PNFI $=0.676$ & Fit \\
& & & & RMSEA $=0.060$ & Fit \\
\hline
\end{tabular}

Table 7

Testing of Hypotheses and Alternative Models

\begin{tabular}{|c|c|c|c|c|c|c|c|c|}
\hline \multirow[b]{2}{*}{ Structural path } & \multirow[b]{2}{*}{$\operatorname{Coef}(\beta)$} & \multirow[b]{2}{*}{ S.D. } & \multirow[b]{2}{*}{$p$ value } & \multirow[b]{2}{*}{ C.R } & \multirow[t]{2}{*}{ Alternative models } & \multirow[b]{2}{*}{$p$ value } & \multirow[b]{2}{*}{ C.R } & \multirow[b]{2}{*}{ Conclusion } \\
\hline & & & & & & & & \\
\hline $\mathrm{IP} \rightarrow \mathrm{CI}$ & 0.642 & 0.158 & $0.000 * *$ & $4.054 * *$ & $\mathrm{IP} \rightarrow \mathrm{CI}$ (only) & $0.000 * *$ & $4.176^{* *}$ & H1 supported \\
\hline $\mathrm{INS} \rightarrow \mathrm{CI}$ & 0.196 & 0.087 & $0.024 *$ & $2.264 *$ & INS $\rightarrow$ CI (only) & $0.035^{*}$ & $2.116^{*}$ & H2 supported \\
\hline $\mathrm{ISI} \rightarrow \mathrm{CI}$ & 0.061 & 0.026 & $0.038^{*}$ & $2.356^{*}$ & ISI $\rightarrow$ CI (only) & $0.046^{*}$ & $2.086^{*}$ & H3 supported \\
\hline $\mathrm{CI} \rightarrow \mathrm{INP}$ & 0.524 & 0.095 & $0.000 * *$ & $5.497 * *$ & $\mathrm{CI} \rightarrow \mathrm{INP}$ (only) & $0.000^{* *}$ & $5.269^{* *}$ & H4a supported \\
\hline $\mathrm{CI} \rightarrow \mathrm{CFP}$ & 0.111 & 0.038 & $0.013^{*}$ & $2.963 *$ & $\mathrm{CI} \rightarrow \mathrm{CFP}$ (only) & $0.029^{*}$ & $2.188^{*}$ & H4b supported \\
\hline $\mathrm{INP} \rightarrow \mathrm{CFP}$ & 0.024 & 0.011 & $0.048^{*}$ & $2.218^{*}$ & INP $\rightarrow$ CFP (only) & $0.032 *$ & $2.149^{*}$ & H5supported \\
\hline
\end{tabular}

Note: **, *statistically significant at the 1 percent and 5 percent levels, respectively.

Table 8

Assessment of Endogeneity Bias using the Heckman Test

\begin{tabular}{ccccc}
\hline Test & $\mathbf{C o e f}(\boldsymbol{\beta})$ & $\boldsymbol{p}$ value & $\mathbf{z}$ & Conclusion \\
\hline IP $\rightarrow$ CI (Selection DV = INP; IV = INS) & 0.414 & $0.000^{* *}$ & $7.65^{* *}$ & No bias present \\
INS $\rightarrow$ CI (Selection DV = INP; IV = ISI) & 0.198 & $0.006^{* *}$ & $3.24^{* *}$ & No bias present \\
ISI $\rightarrow$ CI (Selection DV = INP; IV = IP) & 0.095 & $0.023^{*}$ & $2.38^{*}$ & No bias present \\
CI $\rightarrow$ INP (Selection DV = CFP; IV = INS) & 0.426 & $0.000^{* *}$ & $11.39^{* *}$ & No bias present \\
CI $\rightarrow$ CFP (Selection DV = INP; IV = IP) & 0.117 & $0.018^{*}$ & $2.46^{*}$ & No bias present \\
INP $\rightarrow$ CFP (Selection DV = CI; IV = ISI) & 0.132 & $0.015^{*}$ & $2.37^{*}$ & No bias present
\end{tabular}

Note: DV is dependent variables, IV is independent variables **, *statistically significant at the 1 percentand 5 percent levels, respectively. 
Table 9

Assessment of Nonlinear Effects

\begin{tabular}{ccccc}
\hline Structural path & Coef $(\boldsymbol{\beta})$ & $\boldsymbol{p}$ value & $\boldsymbol{f}^{\mathbf{2}}$ & Ramsey's RESET \\
\hline $\mathrm{IP} * \mathrm{IP} \rightarrow$ CI & 0.080 & 0.178 & 0.004 & \\
$\mathrm{INS}{ }^{*} \mathrm{INS} \rightarrow$ CI & 0.043 & 0.224 & 0.002 & $F(2.348)=0.41, p=0.206$ \\
$\mathrm{ISI}{ }^{*} \mathrm{ISI} \rightarrow$ CI & 0.158 & 0.118 & 0.025 & \\
$\mathrm{CI}{ }^{*} \mathrm{CI} \rightarrow \mathrm{INP}$ & 0.131 & 0.078 & 0.029 & \\
$\mathrm{CI}{ }^{*} \mathrm{CI} \rightarrow$ CFP & 0.216 & 0.155 & 0.038 & $F(1.959)=0.76, p=0.684$ \\
$\mathrm{INP}$ INP $\rightarrow$ CFP & 0.141 & 0.093 & 0.050 & \\
\hline
\end{tabular}

Note: ${ }^{*}, *$ statistically significant at the 1 percent and 5 percent levels, respectively.

Table 10

Assessment of Unobserved Heterogeneity using the FIMIX Method

\begin{tabular}{cccc}
\hline & & Number of segments \\
Criteria & $\mathbf{k}=\mathbf{1}$ & $\mathbf{k}=\mathbf{2}$ & $\mathbf{k}=\mathbf{3}$ \\
\cline { 2 - 4 } & 1265.98 & 1260.48 & $\mathbf{1 2 4 8 . 8 7}$ \\
\hline AIC & $\mathbf{1 2 7 4 . 9 8}$ & 1279.48 & 1277.87 \\
AIC $_{3}$ & $\mathbf{1 2 8 3 . 9 8}$ & 1298.48 & 1306.87 \\
AIC $_{4}$ & $\mathbf{1 2 9 3 . 9 9}$ & 1319.61 & 1339.12 \\
BIC & $\mathbf{1 3 0 2 . 9 9}$ & 1338.61 & 1368.12 \\
CAIC & $\mathbf{1 2 7 7 . 3 5}$ & 1284.48 & 1285.50 \\
HQ & $\mathbf{1 4 7 8 . 0 2}$ & 1708.12 & 1932.11 \\
MDL5 & -623.99 & -611.24 & $\mathbf{- 5 9 5 . 4 4}$ \\
LnL & na & 0.565 & $\mathbf{0 . 6 1 6}$ \\
EN & na & 0.607 & $\mathbf{0 . 6 1 0}$ \\
NFI & na & 72.281 & $\mathbf{6 3 . 6 8 8}$ \\
NEC & & &
\end{tabular}

Note: AIC: Akaike's information criterion; $\mathrm{AIC}_{3}$ : modified AIC with factor 3; $\mathrm{AIC}_{4}$ : modified AIC with factor 4; BIC: Bayesian information criteria; CAIC: consistent AIC; HQ: Hannan Quinn criterion; MDL 5 : minimum description length with factor 5; LnL: Log Likelihood; EN: entropy statistic; NFI: non-fuzzy index; NEC: normalized entropy criterion; na: not available; numbers in bold indicate the best outcome per segment retention criterion. 